\title{
Management of acute basilar artery occlusion: Should any treatment strategy prevail?
}

\author{
Tomas Dornak, Roman Herzig, Daniel Sanak, David Skoloudik
}

\begin{abstract}
Background. Acute basilar artery occlusion (BAO) is relatively infrequent form of acute ischemic stroke associated with severe and persisting neurological deficit and high mortality rate (to $86 \%$ ). Early recanalization is essential for good clinical outcome but the most effective treatment approach remains unestablished. Several treatment strategies are currently available but their safety and efficacy have only been tested in retrospective/prospective case series. Randomized controlled trials (RCTs) are lacking.

Methods and Results. We searched the PubMed database for assessments of recanalization rate and clinical outcome in BAO patients treated with various treatment methods. The results show that antithrombotics are least effective while specific reperfusion therapies including intravenous thrombolysis (IVT) and various types of intra-arterial therapy (IAT) are more so. Less than half of BAO patients reach independent outcome following IVT with a recanalization rate 52 $78 \%$. Even though IAT recanalizes BAO more frequently (in up to 100\%), the higher recanalization rate is not necessarily associated with better outcome.

Conclusions. Good clinical outcome is strongly dependent on recanalization time. Thus, the concept of bridging therapy, combining widely available IVT with IAT, was introduced and is usually considered a rescue strategy in nonresponders to IV alteplase. A trend to better outcome in patients treated with bridging therapy in some studies, has to be confirmed by large RCTs.
\end{abstract}

Key words: ischemic stroke, basilar artery, occlusion, treatment method, recanalization, outcome

Received: April 8, 2013; Accepted: September 20, 2013; Available online: September 27, 2013

http://dx.doi.org/10.5507/bp.2013.075

Department of Neurology, Faculty of Medicine and Dentistry, Palacky University Olomouc and University Hospital Olomouc, Czech Republic Corresponding author: Roman Herzig, e-mail: herzig.roman@seznam.cz

\section{INTRODUCTION}

Acute basilar artery occlusion (BAO) is associated with severe and persistent neurological deficit and high mortality rate. If untreated, the mortality rate can be as high as $86 \%\left(\right.$ ref. $\left.^{1,2}\right)$. This is also the reason why good clinical outcome, in contrast to the anterior circulation, was defined as a value of $0-3$ points in the modified Rankin Scale (mRS) in the majority of studies. Poor clinical outcome is associated more frequently with occlusion of proximal and middle segments ${ }^{3}$ while length of BA occlusion and state of collaterals are additional independent variables affecting survival ${ }^{4,5}$.

Early recanalization is a strong predictor of good BAO outcome ${ }^{6}$, but the most effective therapeutic approach has not been established, yet. Currently, several treatment approaches are available: antithrombotic treatment (AT), intravenous thrombolysis (IVT), intra-arterial treatment (IAT - including intra-arterial thrombolysis, endovascular sonolysis and mechanical thrombectomy) or combinations of these.

According to the European Stroke Organisation (ESO) guidelines, intra-arterial (IA) thrombolysis is recommended for acute BAO in selected patients. IVT for BAO is an acceptable alternative even after $4.5 \mathrm{~h}$ of onset of symptoms ${ }^{7,8}$. Even though the time window is not as strict as it is for anterior circulation, shorter time to recanalization in $\mathrm{BAO}$ is associated with a more favorable outcome while poor outcome is more likely when recanalization therapy is started more than 6 hours after estimated time of BAO ( ref. $\left.^{6}\right)$.

\section{Nonspecific Treatment}

Standard nonspecific treatment includes the administration of either antiplatelet drugs, anticoagulation therapy, or their combination. In BAO, antithrombotics are mostly considered ineffective. After the first case series published in the early 1970's (ref. ${ }^{9}$ ) Archer et al. presented 20 patients treated with either antiplatelets or anticoagulants and they had a mortality rate of $70 \%$ (ref. ${ }^{1}$ ).

Since then, few case reports of patients initially presenting with a severe deficit and substantially improving after nonspecific treatment have been published ${ }^{10,11}$ however, hospital-based series report case fatality up to $86 \%\left(\right.$ ref. $^{1,2,9,12}$ ). As all of these studies were too small to provide solid data, the sample of 82 patients presented by Schonewille et al. provided more accurate data: mortality $40 \%$ and dependency among survivors $65 \%\left(\right.$ ref. $\left.{ }^{13}\right)$. Even though these patients were treated during the time period when thrombolysis was not standard, they were not consecutively pooled out. Eleven patients were excluded because of the intravenous (IV) and IA use of 
thrombolysis, meaning selection bias could play a role as a confounding factor. Moreover, BAO was confirmed only in $30 \%$ of these patients. To date no direct comparison has been made between AT and placebo, or comparison between different types of antiplatelet drugs administered solely without any additional therapy (i.e. IVT, IAT, ...).

In the Basilar Artery International Cooperation Study (BASICS) registry ${ }^{14}, 66 / 183$ (36.1\%) patients treated with AT had good functional outcome (mRS 0-3) after 1 month. In comparison, AT group patients presented with milder neurological deficit in the National Institutes of Health Stroke Scale (NIHSS) (mean 15 points) at the time of treatment than patients in the IVT (mean 21 points) and IAT (mean 25 points) group.

Table 1 shows clinical outcome in BAO patients treated with AT from different studies.

\section{Intravenous Thrombolysis}

IVT, which is widely accessible, is considered standard specific reperfusion therapy in acute ischemic stroke. It can be used prior to transport as bridging in terms of "drip, ship and retrieve protocol" referred earlier by Pfeffekorn et al. as a feasible treatment approach ${ }^{15}$.
The only drug approved by the European Medicines Agency (EMA) for the treatment of ischemic stroke is recombinant tissue plasminogen activator (rt-PA) (ref. ${ }^{16}$ ). Randomized trials show that patients might benefit from IVT up to $4.5 \mathrm{~h}$ after symptom onset ${ }^{17}$. It is known that risk might outweigh benefit beyond $4.5 \mathrm{~h}$ in the anterior circulation. Given that BAO is a rare form of stroke, individuals, suffering from BAO, have barely influenced study. According to the ESO guidelines, IVT for BAO is an acceptable alternative even after $4.5 \mathrm{~h}$ after the onset of symptoms ${ }^{6,7}$.

Several studies reported the efficacy of IVT similar to invasive endovascular therapy reaching good clinical outcome, defined as mRS $0-2$ in $21-53 \%$ and as mRS 0 - 3 in $26-63 \%$ (Table 2) (ref. ${ }^{14,18-21}$ ). The largest single center cohort study from Helsinki comprised 116 patients mostly treated with IVT ( ref. $^{20}$ ). Thirty $(26 \%)$ of these had good 3-month clinical outcome while 48 (41\%) died. Sairanen et al. achieved recanalization in $65 \%$ of IVT patients, reaching the efficacy of local IAT that varied with different endovascular technique between 62.5 and $94 \%$ (ref. ${ }^{14,22-25}$ ). In a systematic analysis comparing IVT and IAT (ref. ${ }^{19}$ ) recanalization rate was higher in the IAT

Table 1. Outcome in conventionally treated patients.

\begin{tabular}{|c|c|c|c|c|c|}
\hline \multirow{2}{*}{ Study } & \multirow{2}{*}{ Year } & \multirow{2}{*}{$\mathrm{n}$} & \multicolumn{2}{|c|}{ modified Rankin Scale } & \multirow{2}{*}{ Mortality (\%) } \\
\hline & & & $0-3(\%)$ & $4-5(\%)$ & \\
\hline Moscow $^{9}$ & 1973 & 9 & 44 & 22 & 33 \\
\hline Archer $^{1}$ & 1977 & 20 & 5 & 25 & 70 \\
\hline $\mathrm{Hacke}^{2}$ & 1988 & 22 & 14 & 0 & 86 \\
\hline Devuyst $^{12}$ & 2002 & 9 & 66 & 22 & 11 \\
\hline Schonewille $^{13}$ & 2005 & 82 & 21 & 39 & 40 \\
\hline BASICS - MtM ${ }^{14}$ & 2009 & 104 & 58 & 30 & 13 \\
\hline BASICS - $S^{14}$ & 2009 & 79 & 8 & 38 & 54 \\
\hline
\end{tabular}

BASICS - Basilar Artery International Cooperation Study; MtM - mild to moderate deficit; $\mathrm{n}$ - number; S - severe deficit

Table 2. Outcome in patients treated with IVT.

\begin{tabular}{|c|c|c|c|c|c|c|c|c|c|}
\hline \multirow{2}{*}{ Study } & \multirow{2}{*}{ Year } & \multirow{2}{*}{$\mathrm{n}$} & \multicolumn{3}{|c|}{ modified Rankin Scale } & \multirow{2}{*}{$\begin{array}{c}\text { Mortality } \\
\text { (\%) }\end{array}$} & \multirow{2}{*}{$\begin{array}{l}\text { Time of } \\
\text { follow-up }\end{array}$} & \multirow{2}{*}{$\begin{array}{l}\mathrm{SICH} \\
(\%)\end{array}$} & \multirow{2}{*}{$\begin{array}{c}\text { Recanalization } \\
\text { rate }(\%)\end{array}$} \\
\hline & & & $0-2(\%)$ & $0-3(\%)$ & $4-5(\%)$ & & & & \\
\hline \multirow[t]{2}{*}{ Lindsberg $^{18}$} & \multirow[t]{2}{*}{2004} & 50 & 22 & 32 & 28 & 40 & 3 months & \multirow{2}{*}{14} & \multirow{2}{*}{52} \\
\hline & & 50 & 30 & 34 & 20 & 46 & 1 year & & \\
\hline Lindsberg, Mattle ${ }^{* 19}$ & 2006 & 76 & 22 & $\mathrm{~N} / \mathrm{A}$ & $\mathrm{N} / \mathrm{A}$ & 50 & varies & 11 & 53 \\
\hline BASICS - MtM ${ }^{14}$ & 2009 & 49 & 53 & 63 & 20 & 16 & 1 month & 6 & 71 \\
\hline BASICS - $\mathrm{S}^{14}$ & 2009 & 72 & 21 & 26 & 28 & 46 & 1 month & 6 & 66 \\
\hline Sairanen $^{20}$ & 2011 & 116 & 26 & 36 & 22 & 41 & 3 months & 16 & 65 \\
\hline Miyagi ${ }^{\#}$ & 2012 & 25 & 48 & $\mathrm{~N} / \mathrm{A}$ & $\mathrm{N} / \mathrm{A}$ & 4 & 3 months & 8 & 78 \\
\hline
\end{tabular}

BASICS - Basilar Artery International Cooperation Study; MtM - mild to moderate deficit; $\mathrm{n}$ - number; S - severe deficit; SICH - symptomatic intracranial hemorrhage

* systematic review of literature up to 2005

\# patients treated with low-dose alteplase $(0.6 \mathrm{mg} / \mathrm{kg})$ 
group $(65 \%)$ than in the IVT group (53\%). There was hardly any chance of favorable clinical outcome for those without recanalization ( $2 \%$ ), but $38 \%$ when achieving at least partial recanalization. However despite these facts, higher recanalization rate was not automatically associated with better clinical outcome.

In the BASICS registry ${ }^{14}$ patients with mild to moderate deficit had similar risk of poor outcome after IVT or AT but presented with better outcome after IVT in comparison with IAT. Patients with severe deficit (coma, locked-in state, tetraplegia) had lower risk of poor outcome after IVT against AT group, but similar when compared to IAT.

A standard dose of rt-PA is $0.9 \mathrm{mg} / \mathrm{kg}$ body weight (maximum $90 \mathrm{mg}$ ), with $10 \%$ of the dose given as a bolus followed by a 60 -minute infusion. The therapeutic efficacy of low-dose IV alteplase for BAO remains unknown. When comparing 25 patients with $\mathrm{BAO}$ and patients suffering from the middle cerebral artery (MCA) occlusion in a Japanese multicenter registry involving 600 stroke patients treated with low-dose $(0.6 \mathrm{mg} / \mathrm{kg})$ alteplase, similar occurrence of symptomatic intracranial hemorrhage $(\mathrm{SICH})$ within the initial $36 \mathrm{~h}$ ( 8 vs. 5\%), independence at 3 months (mRS score 0 - 2; 48 vs. $52 \%$ ), and mortality rate at 3 months ( 4 vs. $6 \%$ ) was found ${ }^{21}$. When compared to previous publications with BAO patients ${ }^{14,18-20}$ the resulting clinical outcome was better with less SICH but the number of patients was too small to reach any conclusion. There also exists a case report of a patient with basilar artery stenosis prior to distal BAO treated 3 days after symptoms (vertical gaze palsy, spontaneous nystagmus, and gait ataxia) onset with low-dose IV administration of $0.125 \mathrm{mg} / \mathrm{kg}$ rt-PA that was continuously infused for $48 \mathrm{~h}$ resulting in favorable clinical outcome (mRS 0) $\left(\right.$ ref. $\left.^{26}\right)$.

\section{Intra-arterial Thrombolysis}

Intra-arterial thrombolysis is the direct introduction of fibrinolytics into the clot at the site of the arterial occlusion through a microcatheter resulting in a local concentration of fibrinolytics high enough to break up the clot while maintaining low systemic concentration to prevent adverse effects and to assess vessel patency and collateral flow. The safety and efficacy of this method was confirmed in the Prolyse in Acute Cerebral Thromboembolism II (PROACT II) trial, the first randomized control trial (RCT) comparing IA thrombolysis with placebo in patients with acute ischemic stroke caused by MCA occlusion ${ }^{27}$.

The first experience with IA thrombolysis (using streptokinase) in patients with vertebrobasilar thromboembolic disease was reported by Zeumer et al in 1983 $\left(\right.$ ref. $\left.{ }^{28}\right)$. Since then, multiple case series were published presenting clinical outcome in patients treated with IA thrombolysis ${ }^{2,4,5,24,25,29-35}$ (see Table 3 ). It is impossible to

Table 3. Outcome in patients treated with intra-arterial thrombolysis.

\begin{tabular}{|c|c|c|c|c|c|c|c|c|c|c|}
\hline \multirow[t]{2}{*}{ Study } & \multirow[t]{2}{*}{ Year } & \multirow[t]{2}{*}{$\mathrm{n}$} & \multicolumn{3}{|c|}{ modified Rankin Scale } & \multirow{2}{*}{$\begin{array}{c}\text { Mortality } \\
(\%)\end{array}$} & \multirow{2}{*}{$\begin{array}{c}\text { Time } \\
\text { of follow-up }\end{array}$} & \multirow[t]{2}{*}{ Agent } & \multirow{2}{*}{$\begin{array}{l}\text { SICH } \\
(\%)\end{array}$} & \multirow{2}{*}{$\begin{array}{l}\text { Recanalization } \\
\text { rate }(\%)\end{array}$} \\
\hline & & & $0-2(\%)$ & $0-3(\%)$ & $4-5(\%)$ & & & & & \\
\hline$\overline{\text { Hacke }^{2}}$ & 1988 & 43 & $\mathrm{~N} / \mathrm{A}$ & 23 & 7 & 70 & discharge & $\mathrm{U}, \mathrm{ST}$ & 9.3 & 44 \\
\hline Brandt ${ }^{4}$ & 1996 & 51 & 20 & 29 & 2 & 69 & $\mathrm{~N} / \mathrm{A}$ & $\mathrm{U}, \mathrm{rt}-\mathrm{PA}$ & 0 & 51 \\
\hline Cross $^{5}$ & 1998 & 24 & 25 & 33 & 4 & 63 & 3 months & $\mathrm{U}$ & $\mathrm{N} / \mathrm{A}$ & $\mathrm{N} / \mathrm{A}$ \\
\hline Eckert ${ }^{30}$ & 2002 & 83 & 23 & $\mathrm{~N} / \mathrm{A}$ & 17 & 60 & 3 months & $\begin{array}{l}\text { U, rt-PA, } \\
\text { rt-PA + L-P }\end{array}$ & $\mathrm{N} / \mathrm{A}$ & 66 \\
\hline Arnold $\mathrm{M}^{29}$ & 2004 & 40 & 35 & $\mathrm{~N} / \mathrm{A}$ & N/A & 42 & 3 months & $\mathrm{U}$ & 5 & 80 \\
\hline Lindsberg*19 & 2006 & 344 & 24 & $\mathrm{~N} / \mathrm{A}$ & 31 & 55 & $\mathrm{~N} / \mathrm{A}$ & varies & 8 & 65 \\
\hline Schulte $^{32}$ & 2006 & 180 & 23 & $\mathrm{~N} / \mathrm{A}$ & $\mathrm{N} / \mathrm{A}$ & 43 & discharge & U, ST, rt-PA & 30 & 74 \\
\hline Smith $^{\# 34}$ & 2007 & 316 & $\mathrm{~N} / \mathrm{A}$ & $\mathrm{N} / \mathrm{A}$ & $\mathrm{N} / \mathrm{A}$ & 56 & $\mathrm{~N} / \mathrm{A}$ & varies & 7 & 64 \\
\hline BASICS - MtM ${ }^{14}$ & 2009 & 92 & 30 & 43 & 34 & 23 & $1 \mathrm{M}$ & varies & 14 & 83 \\
\hline BASICS - $\mathrm{S}^{14}$ & 2009 & 196 & 11 & 17 & 34 & 49 & $1 \mathrm{M}$ & varies & 14 & 69 \\
\hline $\mathrm{Yu}^{25}$ & 2010 & 52 & 42 & $\mathrm{~N} / \mathrm{A}$ & N/A & 39 & discharge & U, rt-PA & 12 & 77 \\
\hline Jung $^{24}$ & 2011 & 106 & 33 & 44 & 15 & 41 & 3 months & $\begin{array}{l}\text { U with on-demand } \\
\text { endovascular } \\
\text { mechanical } \\
\text { recanalization }\end{array}$ & 1 & 70 \\
\hline Chandra $^{33}$ & 2011 & 40 & 35 & 50 & 17 & 33 & $3 \mathrm{M}$ & $\begin{array}{l}\mathrm{U}, \mathrm{H} \text { with } \\
\text { on-demand } \\
\text { endovascular } \\
\text { approach }\end{array}$ & 13 & 83 \\
\hline
\end{tabular}

BASICS - Basilar Artery International Cooperation Study; H - heparin; L-P- lys-plasminogen; MtM - mild to moderate deficit; $\mathrm{n}$ - number; N/A not available; rt-PA- recombinant tissue plasminogen activator; S - severe deficit; SICH -symptomatic hemorrhages; ST - streptokinase; U - urokinase * systematic review of literature up to 2005

\# meta-analysis 
reliably compare the findings of these uncontrolled series, because they differ in method and timing of follow up, patient baseline characteristic, time-to-treatment and use of different drugs. The largest of these studies pooled out 180 patients treated with either urokinase or streptokinase from five German stroke centers with an overall mortality of $43 \%$ (ref. ${ }^{33}$ ). Complete recanalization was achieved in 99 (55\%) patients and partial recanalization in 35 (19\%) patients. Favorable outcome was strongly associated with maintenance of vessel patency $(P<0.001)$ which supports the idea that recanalization is essential for good clinical outcome.

Recanalization therapy of BAO by thrombolytics is not based on the results of RCTs. To date, only one RCT was carried out, comparing IA urokinase and anticoagulation within $24 \mathrm{~h}$ from symptom onset ${ }^{36}$. Good clinical outcome was observed in 4 out of the 8 patients who received IA urokinase compared with 1 out of the 8 patients in the control group. Nevertheless, the set of patients (16) was too small with imbalances in treatment groups (severe patients were more often allocated to the IA thrombolysis group) to give any reliable management recommendation.

In 2007, a large meta-analysis of 10 studies including 316 BAO patients treated with IA thrombolysis was performed by Smith et al. ${ }^{35}$. In this meta-analysis, an overall $64 \%$ recanalization rate, $7 \%$ ICH occurrence and $56 \%$ mortality (significantly lower in recanalized patients versus those without recanalization, $37 \%$ versus $87 \%$, leading to significant $48 \%$ absolute risk reduction of death with successful recanalization; $P<0.001)$ were reported. Similar results were presented by Lindsberg et al. ${ }^{19}$ in the systematic review including 344 patients, out of whom $55 \%$ died, but $23 \%$ reached good clinical outcome (mRS 0 - 2). Recanalization was successful in $65 \%$ of patients and the occurrence of SICH was $8 \%$ in this review.

Different agents have been used for IA thrombolysis, e.g. streptokinase, alteplase, reteplase, urokinase and heparin. Direct comparison of different fibrinolytic agents used for IA thrombolysis is lacking, with the exception of a retrospectively collected set of 55 patients with large vessel occlusion, of whom 33 were treated with reteplase and 22 with urokinase ${ }^{37}$. Eighteen suffered from BAO and it was found that IA thrombolysis with reteplase did not significantly differ in recanalization, outcome, mortality or ICH occurrence compared to IA urokinase or IA prourokinase.

\section{Mechanical Thrombectomy}

Early recanalization has a major influence on clinical outcome in BAO. Thus, new approaches have been studied to achieve and maintain BA patency. Several devices have been developed to enable mechanical clot extraction. Besides BAO, other large vessels (internal carotid artery, MCA) occlusions were usually included in the majority of existing studies.

The MERCI (Mechanical Embolus Removal in Cerebral Ischemia) retriever $^{\circledR}$ (Concentric Medical, Mountain View, CA, USA) was the first mechanical device approved by the FDA. This retriever, constructed of nitinol memory-wire, is delivered to the lesion location in its linear formation. Once deployed, it returns to its coiled shape to engage the clot, then pulled back-ward to the tip of the catheter through which it is aspirated. Lutsepet al. ${ }^{38}$ analyzed data on vertebrobasilar occlusion from MERCI and Multi-MERCI trials. Patients, all treated within $8 \mathrm{~h}$ from symptom onset, reached good clinical outcome in $41 \%$. Recanalization was found in 21 out of the 27 (78\%) patients and patients with successful recanalization tended to have better outcomes. Mortality was 44\%. When comparing patients $(n=305)$ with failed IV rt-PA versus non-IV rt-PA patients, all treated with MERCI $^{\circledR}$ catheter, similar rates of good outcomes, a tendency toward lower mortality, and similar revascularization rates were found in the failed IV rt-PA group ${ }^{39}$. Vertebrobasilar occlusion was represented by 25 (non-IV rt-PA) and 3 (failed IV rt-PA) patients. Good clinical outcome was found in $28 \%$ and $66 \%$ at 3 months with recanalization rate of $76 \%$ and $100 \%$, resp.

The Penumbra system ${ }^{\circledR}$ (Penumbra Inc., Alameda, CA, USA) works by advancing a reperfusion catheter over a neurovascular guide wire at the site of the thrombus. An appropriately sized separator is advanced and retracted through the catheter to dislodge the clot and a suction device grabs the clot for removal. The Penumbra ${ }^{\circledR}$ pivotal stroke trial that led to its approval by the US FDA showed $82 \%$ recanalization rate, $11 \%$ SICH occurrence and, $25 \%$ of patients achieving good clinical outcome (mRS $0-2$ ) $\left(\right.$ ref. $\left.^{40}\right)$. However, only 11 patients with vertebrobasilar occlusion were enrolled to this study. Even better results were reported by Hussain et al., on 157 patients with large vessel occlusion and reaching favorable clinical outcome (mRS 0 - 2) in $41 \%$ (ref. ${ }^{41}$ ). Future studies are needed to assess its efficacy in the BAO.

Stent retrievers have become dominant in the last few years. The Solitaire system (Solitaire ${ }^{\mathrm{TM}} \mathrm{AB}$ and FR, ev3 Inc., Irvine, CA, USA) is based on self-expanding retrievable intracranial stent that is used at the site of the thrombus, withdrawn, and removed with the clot. Mattle et al. ${ }^{42}$ reviewed three pilot studies with a total of 29 patients with BAO and reported at least $90 \%$ recanalization rate, $31 \%$ mortality rate and $45 \%$ favorable outcome ( $\mathrm{mRS} 0-2$ ) among survivors. However, these trials differed in the proportional representation of BAO and pre-post-Solitaire ${ }^{\mathrm{TM}}$ treatment method and proportion ${ }^{43-45}$. In a recent study, Mordasini et al. presented 14 consecutive patients with BAO treated with Solitaire ${ }^{\mathrm{TM}}$ with on demand addition of multimodal therapy approaches, such as for example thromboaspiration, IV and/or IA thrombolysis, and percutaneous transluminal angioplasty/permanent stent placement ${ }^{45}$. At 3 months, good functional outcome (mRS 0 - 2) was observed in $28.6 \%$ (4/14) patients and overall mortality was $35.7 \%(5 / 14)$. Hemorrhagic complications were referred in up to $3 \%$ of BAO patients undergoing mechanical clot extraction ${ }^{43-47}$. Although Solitaire ${ }^{\mathrm{TM}}$ may be used as the first line treatment, difficult situations can arise subsequently requiring additional procedures such as permanent stent or balloon angioplasty ${ }^{46,48}$. In the randomized SWIFT trial that included 113 patients treated within $8 \mathrm{~h}$ from symptom onset ( $2 \%$ with the occlusion in posterior circulation), the Solitaire Flow Restoration 
Device $^{\mathrm{TM}}$ achieved better angiographic, safety, and clinical outcomes than did the Merci Retrieval System ${ }^{\circledR}$ (ref. ${ }^{49}$ ).

\section{Endovascular Sonolysis}

The EKOS ${ }^{\circledR}$ MicroLysUS infusion catheter (EKOS Corporation, Bothell, WA, USA) is a standard microinfusion catheter with a ring sonography transducer at its distal tip that generates a $360^{\circ}$ circumferential pulse wave around the distal tip. The catheter is designed to be used in conjunction with IA thrombolytic infusion. Ultrasound delivers mechanical pressure waves to the clot, thus exposing more thrombus surface to thrombolytic drug reducing treatment time and total lytic dose delivered. EKOS ${ }^{\circledR}$ proved to be feasible method in the management of acute stroke ${ }^{50-52}$. Kuliha et al. compared 7 BAO patients undergoing EkoSonic endovascular sonolysis with controls showing significant reduction in mortality rate (0 vs. $66.7 \%$ of patients, $P=0.013$ ) (ref. ${ }^{53}$ ). The efficacy in BAO still remains to be clarified and comparison with other endovascular techniques is also needed.

\section{Bridging Therapy}

Bridging therapy is a therapeutic approach that uses IVT with subsequent IA thrombolysis or endovascular mechanical therapy, or both. It combines the speed of widely accessible IV agents such as alteplase (mostly in a dose of 0.6 to $0.9 \mathrm{mg} / \mathrm{kg}$ ) (ref..$^{39,54,55}$ ) or glycoprotein IIb/IIIa inhibitors abciximab and tirofiban, with a high recanalization rate of endovascular techniques ${ }^{14,24,44,46}$. Despite published data from 2 meta-analyses supporting bridging therapy as a therapeutic approach in patients with large vessel occlusion ${ }^{56,57}$ recent studies report no significant difference in functional outcome between bridging and IVT alone and endovascular treatment alone ${ }^{58,59}$.

Georgiadis et al. compared IVT vs. combination of IV and IA thrombolysis in his meta-analysis comprising 11 studies with a total of 457 patients $^{57}$. One hundred and forty patients in 4 studies received $0.9 \mathrm{mg} / \mathrm{kg}$ of IV rt-PA while 317 patients in 7 studies received $0.6 \mathrm{mg} / \mathrm{kg}$. Patients in the $0.9 \mathrm{mg} / \mathrm{kg}$ group had higher rates of favorable outcome $(P=0.022)$ and similar rates of SICH $(P=0.70)$. In the meta-analysis performed by Mazighi et al. ${ }^{56}$ and including 559 patients in 15 studies, no difference in recanalization, functional outcome, SICH occurrence or mortality was found between the 2 dosages. Recanalization rate was $69.6 \%$, SICH occurrence $8.6 \%, 48.9 \%$ of patients reached favorable outcome whereas $17.9 \%$ of them died. Shorter time to IV treatment improved both the recanalization rate and the mortality rate. These meta-analyses were limited by variability in both patient population and IA techniques. Additionally, the majority of patients (63\% on average) presented with MCA occlusion.

In the Interventional Management of Stroke (IMS) III trial, 656 patients were randomized, 434 patients to IVT + endovascular therapy and 222 to IVT alone ${ }^{59}$. The proportion of patients with favorable outcome (mRS 0 - 2) at 90 days did not differ significantly according to the treatment (40.8\% with IVT + IAT and $38.7 \%$ with IVT), with similar mortality rate ( 19.1 vs. $21.6 \% ; P=0.52$ ) and the proportion of patients with $\mathrm{SICH}(6.2$ vs. $5.9 \% ; P=0.83)$. In the first phase of this trial, including 284 patients, computed tomography angiography was used infrequently, and patients with NIHSS $\geq 10$ were included only with an assumption of the major arterial occlusion. Stent retrievers were used in only a small number of patients. In addition, only 4 patients with BAO were included. Mean time to groin puncture was $86 \mathrm{~min}$ and mean time from groin to IAT was $44 \mathrm{~min}$. In the IMS III trial, time to endovascular therapy was longer than in IMS I and IMS II trials despite great emphasis on time. Kass-Hout et al. demonstrated similar outcome, revascularization rate, SICH occurrence, and mortality rate in 106 patients treated either by IVT + IAT or IAT alone ${ }^{58}$. Nevertheless, the endovascular group was treated significantly earlier than the combined group ( $125 \pm 40$ vs. $227 \pm 88 \mathrm{~min} ; P<0.0001$ ). Based on these metaanalyses it seems that additional IA approach probably should be started as soon as possible and not considered only as a rescue strategy ${ }^{56}$.

Pfefferkorn showed the feasibility of "drip, ship and retrieve" strategy in 52 BAO patients ${ }^{15}$. Patients undergoing full-dose IVT with a subsequent IAT $(n=26)$ achieved good 90-day clinical outcome (mRS 0 - 2) more frequently than those $(n=26)$ treated with primary IAT with or without bridging with tirofiban ( 38 vs. $12 \% ; P=0.03$ ). Bridging with abciximab prior to IAT application of rt-PA in BAO patients was tested in two other studies reaching favorable clinical outcome (mRS 0 - 3) in 34.9 and $15 \%$, resp. with recanalization rate 83.7 and $85 \%$, resp. ${ }^{22,60}$. Compared to the group treated with IA rt-PA only, higher recanalization rate $(83.7$ vs. $62.5 \% ; P=0.03)$, higher survival rate $(58.1$ vs. $25 \% ; P=0.01$, and larger number of patients with favorable outcome (mRS $0-3 ; 34.9$ vs. $12.5 \% ; P=0.02$ ) were observed in the bridging group.

In our recent retrospective study ${ }^{61}$ of 50 patients, four treatment groups were compared: 1) bridging group (IVT + IAT), 2) IAT only, 3) IVT only, and 4) AT only. Successful recanalization was achieved in $94.1 \%$ IAT patients, $8.3 \%$ IVT patients, and $92.3 \%$ IVT + IAT patients, while no patient from the AT group recanalized. Recanalization rate was significantly higher in patients who achieved favorable (91.7\%) vs. poor (47.4\%) clinical outcome $(P=0.008)$. An apparent trend for better outcome was found in the bridging group, however, results in particular treatment groups were not statistically significantly different.

\section{CONCLUSION}

Acute BAO is associated with severe and persistent neurological deficit, high mortality rate and its early recanalization is substantial. However, higher recanalization rate is not necessarily associated with better outcome. Currently, several treatment methods are available, including combinations and bridging approaches. A trend for better outcome in patients treated with bridging therapy in some studies, has to be confirmed by large RCTs. It seems that additional IA approach should be started as soon as possible and not considered only as a rescue strategy. 


\section{ABBREVIATIONS}

AT, Antithrombotic treatment; BA, Basilar artery; BAO, Basilar artery occlusion; BASICS, Basilar Artery International Cooperation Study; EMA, European Medicines Agency; ESO, European Stroke Organisation; IA, Intra-arterial; IAT, Intra-arterial treatment; IMS, Interventional Management of Stroke; IV, Intravenous; IVT, Intravenous thrombolysis; MERCI, Mechanical Embolus Removal in Cerebral Ischemia; MCA, Middle cerebral artery; mRS, modified Rankin Scale; NIHSS, National Institutes of Health Stroke Scale; rt-PA, recombinant tissue plasminogen activator.

\section{ACKNOWLEDGEMENT}

Partially supported by the grant of the Internal Grant Agency of Ministry of Health of the Czech Republic number NT/11386-5/2010.

Authorship contributions: TD: literature search; TD, RH, DSa, DSk: manuscript writing; TD, RH: study design; TD: data collection; TD, RH: data analysis; TD, RH, DSa, DSk: data interpretation; RH: final approval.

Conflict of interest statement: None declared.

\section{REFERENCES}

1. Archer CR, Horenstein S. Basilar artery occlusion: clinical and radiological correlation. Stroke 1977;8:383-90.

2. Hacke W, Zeumer H, Ferbert A, Brückmann H, del Zoppo GJ. Intraarterial thrombolytic therapy improves outcome in patients with acute vertebrobasilar occlusive disease. Stroke 1988;19:1216-22.

3. Levy El, Firlik AD, Wisniewski S, Rubin G, Jungreis CA, Wechsler LR, Yonas $\mathrm{H}$. Factors affecting survival rates for acute vertebrobasilar artery occlusions treated with intra-arterial thrombolytic therapy: a meta-analytical approach. Neurosurgery 1999;45:539-48.

4. Brandt T, von Kummer R, Müller-Küppers M, HackeW. Thrombolytic therapy of acute basilar artery occlusion. Variables affecting recanalization and outcome. Stroke 1996;27:875-81.

5. Cross DT 3rd, Moran CJ, Akins PT, Angtuaco EE, Derdeyn CP, Diringer MN. Collateral circulation and outcome after basilar artery thrombolysis. AJNR Am J Neuroradiol 1998;19:1557-63.

6. Vergouwen MD, Algra A, Pfefferkorn T, Weimar C, Rueckert CM, Thijs V, Kappelle LJ, Schonewille WJ; Basilar Artery International Cooperation Study (BASICS) Study Group. Time is brain(stem) in basilar artery occlusion. Stroke 2012;43:3003-6.

7. European Stroke Organisation (ESO) Executive Committee; ESO Writing Committee. Guidelines for management of ischaemic stroke and transient ichaemic attack. Cerebrovasc Dis 2008;25:457-507.

8. European Stroke Organisation (ESO) Executive Committee; ESO Writing Committee. Should the time window for intravenous thrombolysis be extended? Available from: http://www.eso-stroke.org/ pdf/ESO_Guideline_Update_Jan_2009.pdf. 2009

9. Moscow NP, Newton TH. Angiographic implications in diagnosis and prognosis of basilar artery occlusion. Am J Roentgenol Radium Ther Nucl Med 1973;119:597-604.

10. Buljan K, Butković-Soldo S, Janculjak D, Gmajnić R, Poljaković Z Candrlić M, Buljan V. Basilar artery occlusion treated conventionally with good outcome. Med Glas (Zenica) 2011;8:296-8.

11. Oster JM, Aggarwal P. Spontaneous recanalization of the basilar artery with conservative management months after symptom onset. Neurol Int 2009;1:e17.

12. Devuyst G, Bogousslavsky J, Meuli R, Moncayo J, de Freitas G, van Melle $\mathrm{G}$. Stroke or transient ischemic attacks with basilar artery stenosis or occlusion: clinical patterns and outcome. Arch Neurol 2002;59:567-73.
13. Schonewille WJ, Algra A, Serena J, Molina CA, Kappelle LJ. Outcome in patients with basilar artery occlusion treated conventionally. J Neurol Neurosurg Psychiatry 2005;76:1238-41.

14. Schonewille WJ, Wijman CA, Michel P, Rueckert CM, Weimar C, Mattle HP, Engelter ST, Tanne D, Muir KW, Molina CA, Thijs V, Audebert H, Pfefferkorn T, Szabo K, Lindsberg PJ, de Freitas G, Kappelle LJ, Algra A. Treatment and outcomes of acute basilar artery occlusion in the Basilar Artery International Cooperation Study (BASICS): a prospective registry study. Lancet Neurol 2009;8:724-30.

15. Pfefferkorn T, Holtmannspötter M, Schmidt C, Bender A, Pfister HW Straube A, Mayer TE, Brückmann H, Dichgans M, Fesl G. Drip, ship, and retrieve: cooperative recanalization therapy in acute basilar artery occlusion. Stroke 2010;41:722-6.

16. Committee for proprietary medical products. Summary information on refferal opinion following arbitration pursuant to article 29 of directive 2001/83EC, for ACTILYSE. Available from: http://www.ema. europa.eu/docs/en_GB/document_library/Referrals_document/ Actilyse_29/WC500010327.pdf

17. Lees KR, Bluhmki E, von Kummer R, Brott TG, Toni D, Grotta JC, Albers GW, Kaste M, Marler JR, Hamilton SA, Tilley BC, Davis SM, Donnan GA, Hacke W; ECASS, ATLANTIS, NINDS and EPITHET rt-PA Study Group, Allen K, Mau J, Meier D, del Zoppo G, De Silva DA, Butcher KS, Parsons MW, Barber PA, Levi C, Bladin C, Byrnes G. Time to treatment with intravenous alteplase and outcome in stroke: an updated pooled analysis of ECASS, ATLANTIS, NINDS, and EPITHET trials. Lancet 2010;375:1695-703.

18. Lindsberg PJ, Soinne L, Tatlisumak T, Roine RO, Kallela M, Häppölä $\mathrm{O}$, Kaste M. Long-term outcome after intravenous thrombolysis of basilar artery occlusion. JAMA 2004;292:1862-6.

19. Lindsberg PJ, Mattle HP. Therapy of basilar artery occlusion: a systematic analysis comparing intra-arterial and intravenous thrombolysis. Stroke 2006;37:922-8.

20. Sairanen T, Strbian D, Soinne L, Silvennoinen H, Salonen O, Artto V, Koskela I, Häppölä O, Kaste M, Lindsberg PJ. Intravenous thrombolysis of basilar artery occlusion: predictors of recanalization and outcome. Stroke 2011;42:2175-9.

21. Miyagi T, Koga M, Shiokawa Y, Nakagawara J, Hasegawa Y, Furui E, Kimura K, Kario K, Okuda S, Yamagami H, Okada Y, Nezu T, Maeda K, Endo K, Minematsu K, Toyoda K. Intravenous Alteplase at 0.6 $\mathrm{mg} / \mathrm{kg}$ for Acute Stroke Patients with Basilar Artery Occlusion: The Stroke Acute Management with Urgent Risk Factor Assessment and Improvement (SAMURAI) Recombinant Tissue Plasminogen Activator Registry. J Stroke Cerebrovasc Dis 2012 Oct 9. [Epub ahead of print] doi: 10.1016/j.jstrokecerebrovasdis.2012.08.013

22. Nagel S, Schellinger PD, Hartmann M, Juettler E, Huttner HB, Ringleb P, Schwab S, Köhrmann M. Therapy of acute basilar artery occlusion: intraarterial thrombolysis alone vs bridging therapy. Stroke 2009;40:140-6.

23. Kashiwagi J, Kiyosue H, Hori Y, Okahara M, Tanoue S, Sagara Y, Abe T, Mori H. Endovascular recanalization of acute intracranial vertebrobasilar artery occlusion using local fibrinolysis and additional balloon angioplasty. Neuroradiology 2010;52:361-70.

24. Jung $S$, Mono ML, Fischer U, Galimanis A, Findling O, De Marchis GM, Weck A, Nedeltchev K, Colucci G, Mordasini P, Brekenfeld C, ElKoussy M, Gralla J, Schroth G, Mattle HP, Arnold M. Three-month and long-term outcomes and their predictors in acute basilar artery occlusion treated with intra-arterial thrombolysis. Stroke 2011;42:194651.

25. Yu YY, Niu L, Gao L, Zhao ZW, Deng JP, Qu YZ, Jiao DR, Yang JQ, Gao GD. Intraarterial thrombolysis and stent placement for acute basilar artery occlusion. J Vasc Interv Radiol 2010;21:1359-63.

26. Veltkamp R, Jacobi C, Kress B, Hacke W. Prolonged low-dose intravenous thrombolysis in a stroke patient with distal basilar thrombus. Stroke 2006;37:9-11.

27. Furlan A, Higashida R, Wechsler L, Gent M, Rowley H, Kase C, Pessin M, Ahuja A, Callahan F, Clark WM, Silver F, Rivera F. Intra-arterial prourokinase for acute ischemic stroke. The PROACT II study: a randomized controlled trial. Prolyse in Acute Cerebral Thromboembolism. JAMA 1999;282:2003-11.

28. Zeumer $\mathrm{H}$, Hacke W, Ringelstein EB. Local intraarterial thrombolysis in vertebrobasilar thromboembolic disease. AJNR Am J Neuroradiol 1983;4:401-4.

29. Hacke W, Zeumer H, Ferbert A, Brückmann H, del Zoppo GJ. Intraarterial thrombolytic therapy improves outcome in patients with acute vertebrobasilar occlusive disease. Stroke 1988;19:1216-22. 
30. Arnold M, Nedeltchev K, Schroth G, Baumgartner RW, Remonda L, Loher TJ, Stepper F, Sturzenegger M, Schuknecht B, Mattle HP. Clinical and radiological predictors of recanalisation and outcome of 40 patients with acute basilar artery occlusion treated with intraarterial thrombolysis. J Neurol Neurosurg Psychiatry 2004;75:857-62.

31. Eckert B, Kucinski T, Pfeiffer G, Groden C, Zeumer H. Endovascular therapy of acute vertebrobasilar occlusion: early treatment onset as the most important factor. Cerebrovasc Dis 2002;14:42-50.

32. Cross DT 3rd, Moran CJ, Akins PT, Angtuaco EE, Diringer MN. Relationship between clot location and outcome after basilar artery thrombolysis. AJNR Am J Neuroradiol 1997;18:1221-8.

33. Schulte-Altedorneburg G, Hamann GF, Mull M, Kühne D, Liebetrau M, Weber W, Brückmann H, Mayer TE. Outcome of acute vertebrobasilar occlusions treated with intra-arterial fibrinolysis in 180 patients. AJNR Am J Neuroradiol 2006;27:2042-7.

34. Chandra RV, Law CP, Yan B, Dowling RJ, Mitchell PJ. Glasgow coma scale does not predict outcome post-intra-arterial treatment for basilar artery thrombosis. AJNR Am J Neuroradiol 2011;32:576-80.

35. Smith WS. Intra-arterial thrombolytic therapy for acute basilar oc clusion: pro. Stroke 2007;38:701-3.

36. Macleod MR, Davis SM, Mitchell PJ, Gerraty RP, Fitt G, Hankey GJ, Stewart-Wynne EG, Rosen D, McNeil JJ, Bladin CF, Chambers BR, Herkes GK, Young D, Donnan GA. Results of a multicentre, randomised controlled trial of intra-arterial urokinase in the treatment of acute posterior circulation ischaemic stroke. Cerebrovasc Dis 2005;20:12-7.

37. Sugg RM, Noser EA, Shaltoni HM, Gonzales NR, Campbell MS, Weir R, Cacayorin ED, Grotta JC. Intra-arterial reteplase compared to urokinase for thrombolytic recanalization in acute ischemic stroke. AJNR Am J Neuroradiol 2006;27:769-73.

38. Lutsep HL, Rymer MM, Nesbit GM. Vertebrobasilar revascularization rates and outcomes in the $\mathrm{MERCI}$ and multi-MERCI trials. J Stroke Cerebrovasc Dis 2008;17:55-7.

39. Shi ZS, Loh Y, Walker G, Duckwiler GR; MERCI and Multi MERC Investigators. Endovascular thrombectomy for acute ischemic stroke in failed intravenous tissue plasminogen activator versus non-intravenous tissue plasminogen activator patients: revascularization and outcomes stratified by the site of arterial occlusions. Stroke 2010;41:1185-92.

40. Penumbra Pivotal Stroke Trial Investigators. The penumbra pivotal stroke trial: safety and effectiveness of a new generation of mechanical devices for clot removal in intracranial large vessel occlusive disease. Stroke 2009;40:2761-8.

41. Hussain SI, Zaidat OO, Fitzsimmons BF. The Penumbra system for mechanical thrombectomy in endovascular acute ischemic stroke therapy. Neurology 2012;79:135-41.

42. Mattle HP, Arnold M, Lindsberg PJ, Schonewille WJ, Schroth G. Basilar artery occlusion. Lancet Neurol 2011;10:1002-14.

43. Costalat V, Machi P, Lobotesis K, Maldonado I, Vendrell JF, Riquelme C, Mourand I, Milhaud D, Héroum C, Perrigault PF, Arquizan C, Bonafé A. Rescue, combined, and stand-alone thrombectomy in the management of large vessel occlusion stroke using the solitaire device: a prospective 50-patient single-center study: timing, safety, and efficacy. Stroke 2011;42:1929-35.

44. Roth C, Mielke A, Siekmann R, Ferbert A. First experiences with a new device for mechanical thrombectomy in acute basilar artery occlusion. Cerebrovasc Dis 2011;32:28-34.

45. Menon BK, Kochar P, Ah-Seng A, Almekhlafi MA, Modi J, Wong JH, Hudon ME, Morrish W, Demchuk AM, Goyal M. Initial experience with a self-expanding retrievable stent for recanalization of large vessel occlusions in acute ischemic stroke. Neuroradiology 2012;54:147-54.

46. Mordasini P, Brekenfeld C, Byrne JV, Fischer U, Arnold M, Heldner MR, Lüdi R, Mattle HP, Schroth G, Gralla J. Technical feasibility and application of mechanical thrombectomy with the Solitaire FR revascularization device in acute basilar artery occlusion. AJNR Am J Neuroradiol 2013;34:159-63.

47. Espinosa de Rueda M, Parrilla G, Zamarro J, García-Villalba B, Hernández F, Moreno A. Treatment of acute vertebrobasilar oc- clusion using thrombectomy with stent retrievers: Initial experience with 18 patients. AJNR Am J Neuroradiol 2013;34;1044-8. doi:10.3174/ajnr.A3329

48. Kim TK, Rhim JK, Lee CJ, Oh SH, Chung BS. The limitations of thrombectomy with Solitaire ${ }^{\mathrm{TM}} \mathrm{AB}$ as first-line treatment in acute ischemic stroke: A single center experience. J Cerebrovasc Endovasc Neurosurg 2012;14:203-9.

49. Saver JL, Jahan R, Levy El, Jovin TG, Baxter B, Nogueira RG, Clark W, Budzik R, Zaidat OO; SWIFT Trialists. Solitaire flow restoration device versus the Merci Retriever in patients with acute ischaemic stroke (SWIFT): a randomised, parallel-group, non-inferiority trial. Lancet 2012;380:1241-9.

50. Mahon BR, Nesbit GM, Barnwell SL, Clark W, Marotta TR, Weill A, Teal PA, Qureshi AI. North American clinical experience with the EKOS MicroLysUS infusion catheter for the treatment of embolic stroke. AJNR Am J Neuroradiol 2003;24:534-8.

51. IMS II Trial Investigators. The Interventional Management of Stroke (IMS) II Study. Stroke 2007;38:2127-35.

52. Jonszta T, Czerný D, Skoloudík D, Böhm M, Klement P, Procházka V. EkoSonicSV endovascular system for recanalization of the basilar artery occlusion. Vasa 2011;40:408-13.

53. Kuliha M, Roubec M, Jonszta T, Krajca J, Czerny D, Krajina A, Langová K, Herzig R, Procházka V, Skoloudík D. Safety and efficacy of endovascular sonolysis using the EkoSonic endovascular system in patients with acute stroke. AJNR Am J Neuroradiol 2013;34:1401-6. doi:10.3174/ajnr.A3416

54. Rubiera $M$, Ribo $M$, Pagola J, Coscojuela $P$, Rodriguez-Luna $D$, Maisterra O, Ibarra B, Piñeiro S, Meler P, Romero FJ, Alvarez-Sabin J, Molina CA. Bridging intravenous-intra-arterial rescue strategy increases recanalization and the likelihood of a good outcome in nonresponder intravenous tissue plasminogen activator-treated patients: a case-control study. Stroke 2011;42:993-7.

55. Bonvin C, Momjian-Mayor I, Sekoranja L, Lövblad KO, Altrichter S, Yilmaz H, Pereira VM, Loulidi J, Comelli M, Burkhard PR, Sztajzel RF. Stroke severity and residual flow determined by transcranialcolourcoded ultrasound (TCCD) predict recanalization and clinical outcome during thrombolysis. J Neurol Sci 2010;296:96-100.

56. Mazighi M, Meseguer E, Labreuche J, Amarenco P. Bridging therapy in acute ischemic stroke: a systematic review and meta-analysis. Stroke 2012;43:1302-8.

57. Georgiadis $A L$, Memon MZ, Shah QA, Vazquez G, Suri MF, Lakshminarayan K, Qureshi Al. Comparison of partial $(.6 \mathrm{mg} / \mathrm{kg})$ versus full-dose $(.9 \mathrm{mg} / \mathrm{kg})$ intravenous recombinant tissue plasminogen activator followed by endovascular treatment for acute ischemic stroke: a meta-analysis. J Neuroimaging 2011;21:113-20.

58. Kass-Hout T, Kass-Hout O, Mokin M, Thesier DM, Yashar P, Orion D, Jahshan S, Hopkins LN, Siddiqui AH, Snyder KV, Levy El. Is bridging with intravenous thrombolysis of any benefit in endovascular therapy for acute ischemic stroke? World Neurosurg 2013 Jan 31. [Epub ahead of print] doi:10.1016/j.wneu.2013.01.097

59. Broderick JP, Palesch YY, Demchuk AM, Yeatts SD, Khatri P, Hill MD Jauch EC, Jovin TG, Yan B, Silver FL, von Kummer R, Molina CA Demaerschalk BM, Budzik R, Clark WM, Zaidat OO, Malisch TW, Goyal M, Schonewille WJ, Mazighi M, Engelter ST, Anderson C, Spilker J, Carrozzella J, Ryckborst KJ, Janis LS, Martin RH, Foster LD, Tomsick TA; the Interventional Management of Stroke (IMS) III Investigators. Endovascular therapy after intravenous t-PA versus t-PA alone for stroke. N Engl J Med 2013;368:893-903.

60. Barlinn K, Becker U, Puetz V, Dzialowski I, Kunz A, Kepplinger J, von Kummer R, Gahn G. Combined treatment with intravenous abciximab and intraarterial tPA yields high recanalization rate in patients with acute basilar artery occlusion. J Neuroimaging 2012;22:167-71.

61. Dorňák T, Herzig R, Šaňák D, Král M, Veverka T, Bártková A, Hluštík P, Školoudík D, Heřman $M$, Roubec $M$, Kuliha $M$, Procházka V, Kocher $M$, Kaňovsky P. Acute basilar artery occlusion: safety and efficacy of different treatment strategies and predictors of good outcome [abstract]. Eur J Neurol 2012;19(Suppl 1):154. 